\title{
Enzyme immunoassay of mumps virus in cell culture with peroxidase-labelled virus specific monoclonal antibodies and its application for determination of antibodies
}

Frank H. van Tiel, Cornelis A. Kraaijeveld, Juul Baller, Theo Harmsen, Tom A.M. Oosterlaken and Harm Snippe

Laboratory of Microbiology, State University of Utrecht, Catharijnesingel 59, Utrecht, The Netherlands

(Accepted 9 May 1988)

\section{Summary}

Mumps neutralizing monoclonal antibodies (MAs) were purified and labelled with horseradish peroxidase and used to detect virus-infected Vero cells, which were seeded as monolayers in wells of 96-well plates. This direct enzyme immunoassay (EIA) in cell culture proved to be a sensitive method for detection and titration of mumps virus and it may be useful for diagnostic purposes. The EIA is also suitable for the rapid determination of neutralizing antibodies. Neutralization of mumps virus by preincubation with either monoclonal or polyclonal antibodies was indicated by inhibition of the absorbance at $450 \mathrm{~nm}$ as measured with a multichannelled photometer. The EIA (duration 2 days) for determination of mumps neutralizing antibodies is an attractive alternative for the plaque reduction test (duration 6 days).

Mumps virus; Monoclonal antibody; Neutralization; Enzyme immunoassay

\section{Introduction}

Virus specific monoclonal antibodies (MAs) can be employed in direct or indirect enzyme immunoassay (EIA) for the detection of virus (Cevenini et al., 1984;

Correspondence to: C.A. Kraaijeveld, Laboratory of Microbiology, State University of Utrecht, Catharijnesingel 59, 3511 GG Utrecht, The Netherlands. 
Nowinski et al., 1983). Recently (Van Tiel et al., 1984) we described an EIA in cell culture for Semliki Forest virus (SFV). We adapted this assay to titrate virus inhibition by interferon, antiviral agents and immune serum (Van Tiel et al., 1985, $1986 \mathrm{a}, \mathrm{b}$ ). Virus inhibition, measured as reduction in absorbance value at $450 \mathrm{~nm}$. was shown to be dependent on the concentration of the inhibitor. The ElA was performed with HRPO-labelled SFV-specific MAs, which were added to SFV-infected $\mathrm{L}$ cell monolayers in wells of 96 -well plates. In this paper we extend our studies to mumps virus, which replicates slowly compared to SFV.

\section{Materials and Methods}

Virus

Mumps virus was isolated from a patient on primary monkey kidney cells and passed over Hep- 2 cells. The sixth passage, containing about $5 \times 10^{5}$ plaque forming units (PFU) was used to inoculate Vero cell monolayers in Roux bottles at a multiplicity of infection (MOI) of 0.0004 . The medium was replaced at day 3 of incubation at $37^{\circ} \mathrm{C}$. At day 5 the monolayers were rinsed (with medium) and subsequently incubated for $18 \mathrm{~h}$ at $37^{\circ} \mathrm{C}$ with medium without calf serum. Thereafter, the supernatant fluids were collected for virus concentration by ultracentrifugation. The resulting mumps virus suspension contained $1.1 \times 10^{8}$ PFU per $\mathrm{ml}$ and agglutinated guinea pig erythrocytes $(1 \%)$ to a dilution of $1 / 1600$. The virus was stored at $-70^{\circ} \mathrm{C}$ in small portions and used for primary immunization of mice and inoculation of Vero cells to be used in EIA. An egg-adapted strain of mumps virus was used for booster immunization. The haemagglutination titre of pooled amnion fluid, collected from hen's embryonated eggs 6 days after virus inoculation, was 1/1000. Plaque titration, fifty percent plaque reduction test $\left(\mathrm{PRT}_{50}\right)$, haemagglutination inhibition (HAI), haemadsorption inhibition (HADI), and other general virological methods have been described previously (Norrby, 1985; Wagenvoort et al., 1980).

\section{Cells and media}

In this study we used Vero cells only. Autoclavable Eaglc's medium (Yamane Matsuya and Jimbo, 1968), supplemented with 5\% heat-inactivated calf serum, $1 \%$ yeast extract and antibiotics, was used throughout this study. As buffer either 0.06 M $N$-2-hydroxyethyl-piperazine- $N^{\prime}$-ethanesulfonic acid (Hepes) or $0.04 \mathrm{M}$ sodium bicarbonate was used.

\section{Animals and immunization}

For mumps virus specific plasma cell induction, female BALB/c mice of about 12 weeks of age were injected intraperitoneally with $0.5 \mathrm{ml}$ of $1: 3$ diluted Vero cell derived mumps virus (about 100 haemagglutinating units, HAU) mixed with 200 $\mu \mathrm{g}$ of the adjuvant dimethyl dioctadecyl ammonium bromide (DDA) which was obtained from Eastman Kodak, Rochester, New York. At day 34 one mouse was boosted intravenously with $0.5 \mathrm{ml}$ of undiluted egg-derived mumps virus $(500$ 
HAU). Another mouse was boosted similarly at day 35. Egg-derived mumps virus instead of Vero cell derived was used to boost immune reactions against the virus itself but not against contaminating Vero cell antigens. At day 38 of immunization the spleens of the two mice were pooled and used for hybridoma production.

\section{MA production and characterization}

Spleen cells from immunized mice were fused with the myeloma line P3-X63AG8.653 (Kohler, Howe and Milstein, 1976) as described by Fazekas de St. Groth and Scheidegger (1980). After 2 weeks, the cultures were screened for antibody production by indirect enzyme-linked immunosorbent assay (ELISA) as described earlier for Semliki Forest virus (Boere et al., 1984) and by haemadsorption inhibition (HADI) on mumps-infected Vero cell monolayers in flat-bottomed 96-well plates (Catalog No. 3596; Costar Plastics, Cambridge, Mass., U.S.A.). In the solid phase ELISA egg-grown mumps virus was used and in the HADI Vero cell grown virus. Clones positive in both antibody tests were used for ascitic fluid production by injecting $10^{6}$ to $5 \times 10^{6}$ subcloned cells into pristane-primed BALB/c mice. After about 10 days, mouse ascitic fluids were collected and used for purification of antimumps immunoglobulins by the protein A-Sepharose method (Ey et al., 1978). The protein content of MA preparations was determined according to the method described by Lowry et al. (1951). The immunoglobulin subclasses were determined by ELISA as described earlier (Boere et al., 1983).

\section{Conjugation of MAs with HRPO}

HRPO (Boehringer, Mannheim, F.R.G.) was conjugated to purified MAs by the periodate method (Nakane and Kawaoi, 1974).

\section{Detection of mumps antigen in cell culture with a direct EIA}

Vero cell derived mumps virus was diluted in medium and added in $0.025 \mathrm{ml}$ volumes to wells of flat-bottomed 96-well plates (Costar Plastics). To control wells only medium was added. Then into each well $5 \times 10^{4}$ Vero cells $(0.1 \mathrm{ml})$ were seeded to form monolayers. The plates with infected and control cells were incubated at $36.5^{\circ} \mathrm{C}$ or $37^{\circ} \mathrm{C}$. After selected time intervals the supernatant fluids were discarded, and the cells were fixed by addition of $0.05 \%$ glutaraldehyde (E. Merck AG, Darmstadt, F.R.G.) and incubated for $10 \mathrm{~min}$ at room temperature. The plates were washed with tapwater, rinsed with phosphate-buffered saline (PBS), $\mathrm{pH} 7.2$, and finally shaken dry. HRPO-labelled MA suitably diluted in PBS, with $1 \%$ calf serum and $0.5 \%$ Tween 20 , was added in $0.05 \mathrm{ml}$ aliquots and incubated for $1 \mathrm{~h}$ at $37^{\circ} \mathrm{C}$. The plates were washed thrice with PBS and shaken dry. The substrate for HRPO, tetramethylbenzidine ureaperoxide, was added in $0.05 \mathrm{ml}$ portions and incubated for $30 \mathrm{~min}$ at room temperature. The reaction was stopped with $0.05 \mathrm{ml}$ of $0.018 \mathrm{M} \mathrm{H}_{2} \mathrm{SO}_{4}$. Absorbance values were read at $450 \mathrm{~nm}$ with a Titertek Multiscan photometer (Flow Laboratories, Irvine, Scotland, U.K.).

Mumps virus neutralization determined with enzyme immunoassay in cell culture Volumes of $0.025 \mathrm{ml}$ medium, containing diluted mumps virus, were added to 
$0.025 \mathrm{ml}$ dilutions of either MA or immune serum in wells of 96-well plates (Costar Plastics). The virus-antibody mixtures were incubated for $1 \mathrm{~h}$ at $37^{\circ} \mathrm{C}$ and subsequently $0.01 \mathrm{ml}$ (single- or morefold) of each mixture was pipetted into wells of other 96 -well plates. Then $0.1 \mathrm{ml}$ of a suspension of Vero cells $\left(50 \times 10^{4} / \mathrm{ml}\right)$ was added to each well and non-neutralized mumps virus was allowed to multiply at $36.5^{\circ} \mathrm{C}$ (or $37^{\circ} \mathrm{C}$ ). After selected time intervals the monolayers were fixed and subsequently the EIA was performed.

\section{Results}

Production and characterization of mumps-specific $M A$

Screening after fusion of the hybridoma supernatants with ELISA and a HADI technique yielded numerous clones positive in both tests. On the basis of their fast growth 10 clones were selected for further study. In the present study we used three MAs, respectively: UM 1B, UM 4B and UM 10B. The HAI-titres of protein ASepharose purified MAs ( $2 \mathrm{mg}$ protein per $\mathrm{ml}$ ) are respectively: $1 / 150,1 / 1000$ and $1 / 1000$. The HADI-titres of these MAs were $1 / 1500,1 / 30000$ and $1 / 30000$, re-

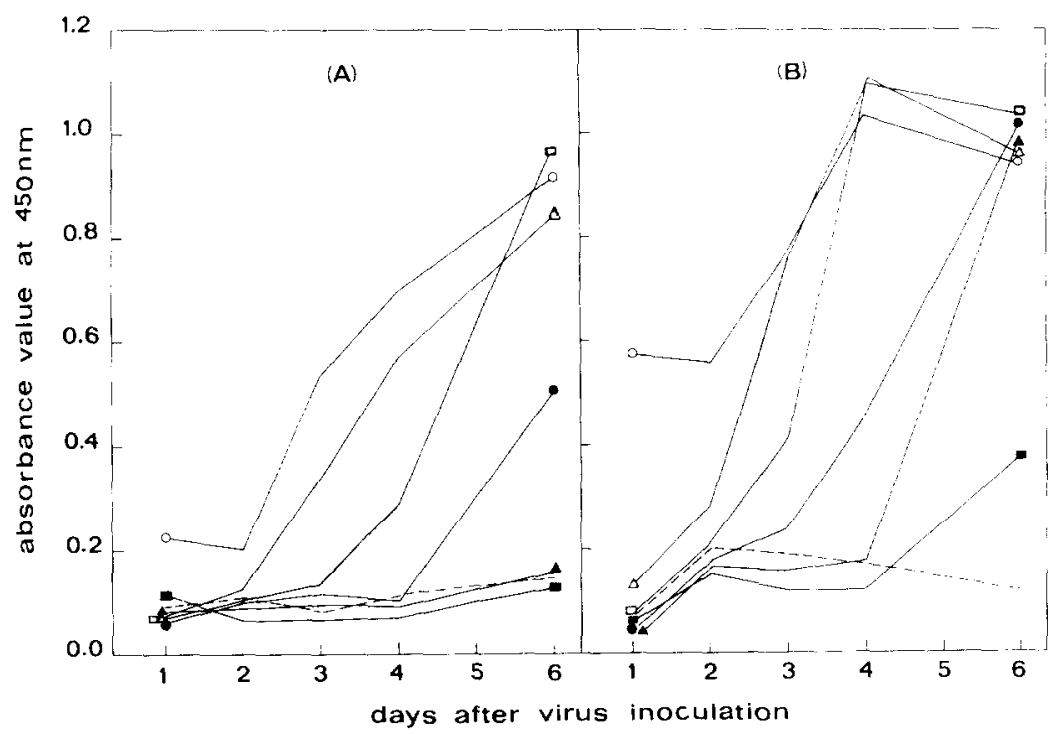

Fig. 1. Detection of mumps virus in cell culture with HRPO-labelled MA. Suspensions of Vero cells in 96-well plates were infected with serial dilutions of mumps virus. The medium was buffered either with Hepes (A) or sodium bicarbonate (B). At various time intervals after infection $(1,2,3,4$ and 6 days) the monolayers of Vero cells were fixed and subsequently the EIA was performed with HRPOlabelled MA UM 10B (1/20000). Symbols for mean $(n=4)$ absorbance values measured against Vero cells at different $-\log _{10}$ dilutions of mumps virus: 0,$3 ; \Delta, 4 ; 0,5 ; \bullet, 6 ; \Delta, 7 ;$ and $\boldsymbol{\square}, 8$. Mean $(n=4)$ absorbance values measured at each day against non-infected Vero cells are connected by the abridged lines. 
spectively. The ELISA for determination of immunoglobulin subclasses revealed that all three MAs most probably belonged to the IgG2a subclass.

\section{Detection of mumps virus in cell culture by use of HRPO-labelled MA}

Mumps virus was serially diluted ( $-\log _{10}$ dilution $3,4,5,6,7$ and 8 ). Each dilution of virus was pipetted fourfold $(0.05 \mathrm{ml}$ per well) into wells of microtiter plates just before $5 \times 10^{4}$ Vero cells $(0.1 \mathrm{ml})$ were added to form monolayers. Both virus and cells were diluted in medium, buffered either with $0.06 \mathrm{M}$ Hepes or $0.04 \mathrm{M}$ sodium bicarbonate. Plates with Hepes-buffered medium were incubated at $36.5^{\circ} \mathrm{C}$ in a normal stove while plates with sodium bicarbonate-buffered medium were held at $36.5^{\circ} \mathrm{C}$ in a $\mathrm{CO}_{2}$-incubator. At various time intervals after virus inoculation (1, 2, 3, 4 and 6 days) the Vero cell monolayers, infected and noninfected, were fixed with glutaraldehyde, washed with tapwater, rinsed with PBS and stored at $+4^{\circ} \mathrm{C}$ till day 6. At that day all plates were tested for the presence of mumps virus with HRPO-labelled MA UM 10B. The mean absorbance values determined at each dilution of virus and each day are presented in Fig. 1A and B. The figures show that detection of mumps virus depends on virus input, length of the infection period and the buffer in medium. Monolayers inoculated with the highest dose of mumps virus ( $-\log _{10}$ dilution: 3.0 ) are all positive in the EIA within $24 \mathrm{~h}$. In contrast monolayers inoculated with the lowest doses of virus $\left(-\log _{10}\right.$ dilution: 7.0 and

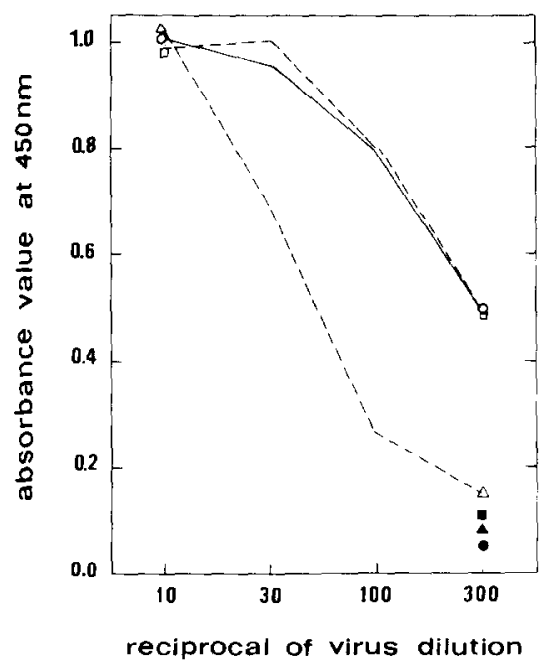

Fig. 2. Inhibition of mumps virus multiplication by mouse antiserum as detected with EIA. Dilutions $(1 / 10,1 / 30,1 / 100$ and $1 / 300)$ of mumps virus were mixed and incubated with either mouse antiserum against mumps (dilution 1/30) or mouse antiserum against Semliki Forest virus (dilution 1/30) before Vero cells were added. The virus-infected cells were incubated for 15 h at $37^{\circ} \mathrm{C}$. Subsequently the EIA was performed with HRPO-labelled MA UM 4B (1/10000). Symbols for absorbance values: $(0)$ control without antiserum, $(\triangle)$ anti-mumps serum and $(\square)$ anti-SFV serum. The single symbols represent corresponding absorbance values measured against non-infected Vero cells. All points plotted are val- 
8.0) were all negative on day 4 of infection; however, some monolayers did become positive on day 6 . Vero cell monolayers inoculated with a $-\log _{10}$ dilution 7.0 of mumps virus were all positive at day 6 provided the medium was buffered with sodium bicarbonate (Fig. 1B). In contrast, the corresponding monolayers $\left(-\log _{10}\right.$ dilution: 7.0) with Hepes-buffered medium were all negative for mumps virus (Fig. 1A). The results indicate that use of sodium bicarbonate allows detection of lower quantities of infectious mumps virus than Hepes.

\section{Determination of neutralizing antibodies to mumps virus}

Preincubation of mumps virus with specific immune serum leads to reduction of viral input and thereby to diminished virus multiplication indicated by lower absorbance values measured against infected Vero cells as demonstrated in the following experiment. Mumps virus was diluted $(1 / 10,1 / 30,1 / 100$ and 1/300) in sodium bicarbonate-buffered medium, supplemented with $3 \%$ fetal calf serum (FCS), and added in $0.025 \mathrm{ml}$ aliquots to wells containing $0.025 \mathrm{ml}$ of either mouse serum (dilution 1/30) against mumps virus, mouse serum (dilution 1/30) against Semliki Forest virus or only medium. The virus-serum mixtures were incubated for $1 \mathrm{~h}$ at $37^{\circ} \mathrm{C}$ before $10^{4}$ Vero cells $(0.1 \mathrm{ml})$ were added. After $15 \mathrm{~h}$ incubation at $37^{\circ} \mathrm{C}$ the monolayers of Vero cells were fixed and the EIA was performed subsequently. As

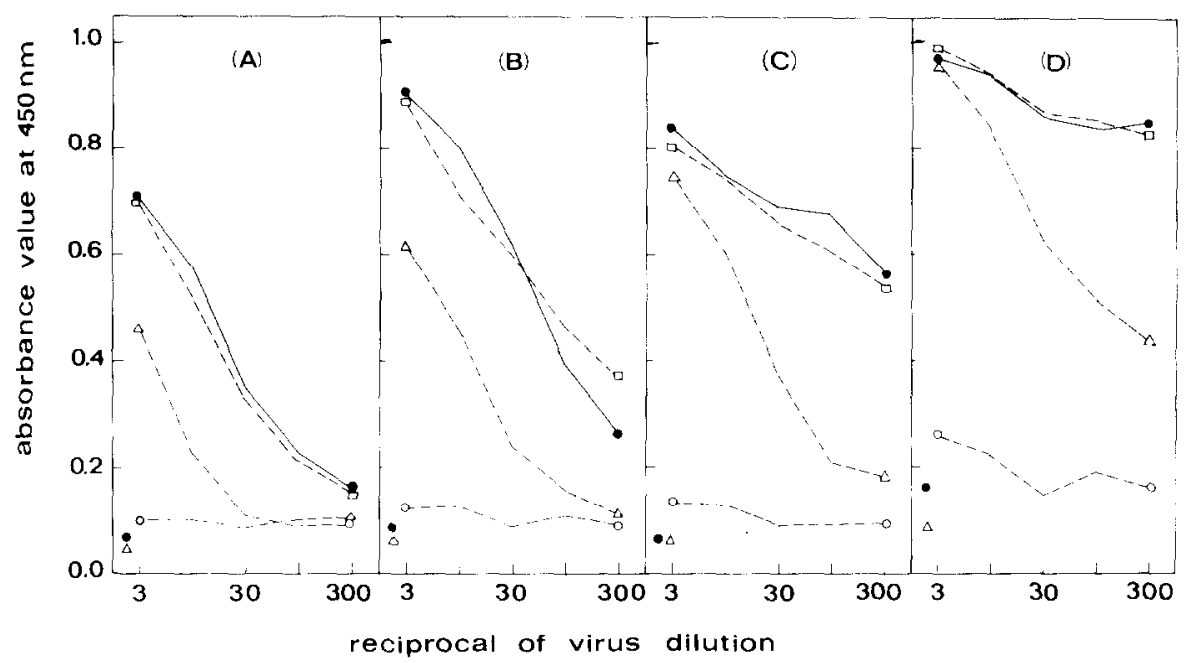

Fig. 3. Determination of mumps specific MA by EIA at various time intervals after virus inoculation. Dilutions $(1 / 3,1 / 10,1 / 100$ and $1 / 300)$ of mumps virus were mixed with dilutions $(1 / 100,1 / 1000$ and $1 / 10000)$ of MA UM $1 \mathrm{~B}$ containing ascitic fluid. After $1 \mathrm{~h}$ incubation at $37^{\circ} \mathrm{C}$ the volumes $(2 \times 0.025$ $\mathrm{ml}$ ) of the mixtures were expanded with $0.2 \mathrm{ml}$ medium. Aliquots of $0.025 \mathrm{ml}$ of the virus-antibody mixtures were pipetted in wells of 96-well plates (one plate for each period of infection) before addition of $5 \times 10^{4}$ Vero cells $(0.1 \mathrm{ml})$. After respectively 40 (A), 48 (B), 56 (C) and $64 \mathrm{~h}$ (D) inculation at $37^{\circ} \mathrm{C}$ the EIA was performed with HRPO-labelled MA UM 4B (1/10000). Symbols for absorbance

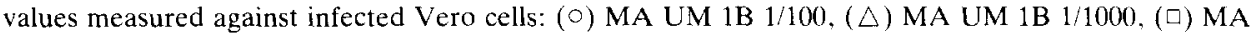
UM 1B $1 / 10000,(\bullet)$ control without MA. The single symbols represent absorbance values measured against non-infected cells. All points plotted are values for single measurements. 
shown in Fig. 2 preincubation of mumps virus with anti SFV serum had no inhibiting effect in the EIA. In contrast, preincubation with anti-mumps serum of the higher dilutions $(1 / 30,1 / 100$ and 1/300) of mumps virus lowered the absorbance at $450 \mathrm{~nm}$ considerably. No reduction in absorbance was found with $1 / 10$ dilution of mumps virus.

Reduction of absorbance value by specific antibody is not only dependent on virus input (Fig. 2) but also on the length of the infection period as shown in the next experiment. Mumps virus was diluted $(1 / 3,1 / 10,1 / 30,1 / 100$ and 1/300) in Hepes-buffered medium and added in $0.025 \mathrm{ml}$ aliquots to wells containing 0.025 $\mathrm{ml}$ of either medium or serial dilutions (1/100, 1/1000 and 1/10000) of MA UM 1B (ascitic fluid). After $1 \mathrm{~h}$ incubation at $37^{\circ} \mathrm{C} 0.2 \mathrm{ml}$ medium was added to each virus-serum mixture. From each mixture aliquots of $0.025 \mathrm{ml}$ were added to 4 separate plates before $5 \times 10^{4}$ Vero cells $(0.1 \mathrm{ml})$ were seeded into each well. The plates were incubated at $37^{\circ} \mathrm{C}$. At graded time intervals $(40,48,56$ and $64 \mathrm{~h})$ after virus inoculation the infected and non-infected Vero cell monolayers were fixed, washed with tapwater and rinsed with PBS. At day 3 all monolayers were tested for mumps virus antigen with HRPO-labelled MA UM 1B. The results of this experiment are shown in Fig. 3A-D. After infection periods of 40 and $48 \mathrm{~h}$, respectively, the absorbance value measured is dependent on the viral input. A dilution of $1 / 1000$ of MA UM $1 B$ reduces the absorbance values at each viral input when mumps virus was allowed to replicate for 40 or $48 \mathrm{~h}$. In contrast, after a multiplication period of $64 \mathrm{~h}$ the absorbance values measured are approximately equal.

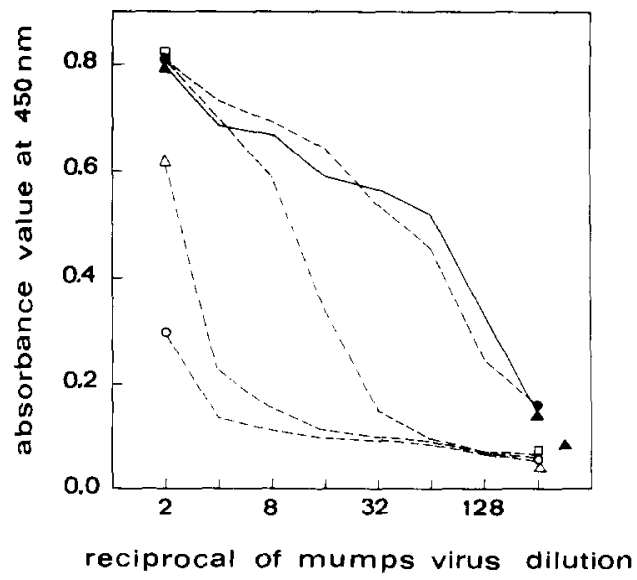

Fig. 4. Detection with EIA of mumps virus neutralizing antibody in human serum. Two-step dilutions $(1 / 2$ to $1 / 256)$ of mumps virus were mixed with dilutions $(1 / 3,0 ; 1 / 10, \triangle ; 1 / 30, \square$; and $1 / 100, \bullet)$ of a human antiserum with a $\mathrm{PRT}_{50}$ of approximately 30 . After $1 \mathrm{~h}$ incubation at $37^{\circ} \mathrm{C} 0.01 \mathrm{ml}$ of each mixture was added to $2 \times 10^{4}$ Vero cells $(0.1 \mathrm{ml})$ in 96-well plates. The infected Vero cells were incubated for $24 \mathrm{~h}$ at $37^{\circ} \mathrm{C}$. Subsequently the EIA was performed with HRPO-labelled MA UM 4B (1/10000). The dashed lines (symbols, see above) represent absorbance values measured in the presence of antiserum. The unbroken line and the single symbol represent control (without antiserum) absorbance values measured against infected and non-infected Vero cells, respectively. All points plotted are values for single measurements. 
The usefulness of the assay for titration of human serum is demonstrated by the next experiment. A human antiserum (from one of us) with a $\mathrm{PRT}_{50}$ of approximately $1 / 30$ was diluted $1 / 3,1 / 10,1 / 30$ and $1 / 100$ and added in volumes of 0.025 $\mathrm{ml}$ to two-step dilutions $(0.025 \mathrm{ml}: 1 / 2$ to $1 / 256)$ of mumps virus. After $1 \mathrm{~h}$ incubation at $37^{\circ} \mathrm{C} 0.01 \mathrm{ml}$ of each virus-serum mixture was added to $2 \times 10^{4}$ Vero cells $(0.1 \mathrm{ml})$ in wells of 96 -well plates. Mumps virus, serum and Vero cells were diluted in $0.1 \mathrm{M}$ Hepes-buffered medium supplemented with $5 \%$ FCS Subsequently the plates were incubated for $24 \mathrm{~h}$ at $37^{\circ} \mathrm{C}$. Then the EIA in cell culture was performed. The results are shown in Fig. 4. The assay detects mumps virus neutralizing antibodies in human serum and again the sensitivity of the ElA proved to be dependent on the viral input. The reduction of absorbance value by $1 / 30 \mathrm{di}-$ luted antibody is greatest for mumps virus dilutions $1 / 32$ and $1 / 64$. In contrast, for virus dilutions $1 / 2$ and $1 / 4$ no differences in absorbance values are observed.

\section{Discussion}

Previously we described a direct EIA for the detection of Semliki Forest virus in cell culture using HRPO-labeled SFV specific MAs (Van Tiel et al., 1984). The present study shows that a similar test is also suitable for the detection of mumps virus. During maturation of both SFV and mumps virus, viral glycoproteins are protruding through the cell membrane facilitating the recognition of these glycoproteins by enzyme-labelled virus-specific MAs. However, SFV has a relatively short multiplication cycle compared to mumps virus and therefore plaque titration of infectious SFV takes 1 day (Boere et al. 1984) compared to 6 days with mumps virus (Wagenvoort et al., 1980). In this study we used three MAs which inhibit both haemagglutination and haemadsorption. Furthermore these MAs neutralize mumps virus. According to Örvell (1984) such MAs most likely recognize the haemagglutinin-neuraminidase protein.

The EIA for titration of infectious mumps virus is at least as sensitive as plaque titration. With the EIA the fifty percent tissue culture infective dose $\left(\mathrm{TCID}_{50}\right)$ titre of a concentrated mumps virus suspension was approximately $10^{9} / \mathrm{ml}$ (Fig. 1) compared to $10^{8} \mathrm{PFU} / \mathrm{ml}$ as determined with the conventional plaque test. For titration of mumps virus with EIA sodium bicarbonate buffered medium was more useful than Hepes buffered medium. However, for antibody determinations with EIA Hepes is a quite suitable buffer. High doses of virus are detected immediately after inoculation of Vero cells or within $48 \mathrm{~h}$ after sufficient multiplication. The absorbance values measured against mumps infected Vero cell monolayers are dependent on the MOI and on the length of the infection period. This is clearly demonstrated by the experiment presented in Fig. 3. After infection periods of 40 and $48 \mathrm{~h}$ the absorbance values measured constitute the steep slope of the S-shaped EIA curve (Fig. 3A,B). After an extended infection period till $64 \mathrm{~h}$, with the same MOIs, all absorbance values attain the shoulder of the EIA curve and thus become about equal (Fig. 3D). Therefore in the ElA neutralization of mumps virus by either MA (Fig. 3) or antiserum (Fig. 2) is demonstrated best with a relatively 
low virus dose, which corresponds to an absorbance value high on the steep slope but not on the shoulder of the EIA curve (Figs. 3,4). The advantages of an EIA in cell culture for mumps neutralizing antibodies are rapidity, objectivity and ease of performance. A plaque reduction test in our hands (Wagenvoort et al., 1980) takes 5 to 6 days compared to a mean time of two days with the EIA.

It proved to be useful to pretest calf serum on inhibition of mumps virus multiplication. Indeed some lots of calf serum gave low levels of inhibition of absorbance and some did not (results not shown). FCS caused no inhibition.

In conclusion, we developed a sensitive EIA in cell culture for detection of mumps virus which could be adapted for rapid determination of neutralizing antibodies.

\section{References}

Boere, W.A.M., Benaissa-Trouw, B.J., Harmsen, M., Kraaijeveld, C.A. and Snippe, H. (1983) Neutralizing and non-neutralizing monoclonal antibodies to the $\mathrm{I}$ glycoprotein of Semliki Forest virus can protect mice from lethal encephalitis. J. Gen. Virol. 64, 1405.

Boere, W.A.M., Hannsen, M., Vinjé, J., Benaissa-Trouw, B.J., Kraaijeveld, C.A. and Snippe, H. (1984) Identification of distinct antigenic determinants on Semliki Forest virus by using monoclonal antibodies with different antiviral activities. J. Virol. 52, 575.

Cevini, R., Donati, M., Moroni, A., Franchi, L. and Rumpianesi, F. (1983) Rapid immunoperoxidase assay for detection of respiratory syncytial virus in nasopharyngeal secretions. J. Clin. Microbiol. $18,947$.

Ey, P.L., Prowse, S.J. and Jenkin, C.R. (1978) Isolation of pure IgG1, IgG2a and IgG2b immunoglobulins from mouse serum using protein A-Sepharose. Immunochemistry 15, 429.

Fazekas de St. Groth, S. and Scheidegger, D. (1980) Production of monoclonal antibodies: strategy and tactics. J. Immunol. Methods 35, 1.

Kohler, G., Howe, S.W. and Milstein, C. (1976) Fusion between immunoglobulin-secreting and nonsecreting myeloma cell lines. Eur. J. Immunol. 6, 292.

Lowry, O.H., Rosebrough, N.J., Farr, A.L. and Randall, R.J. (1951) Protein measurement with the Folin phenol reagent. J. Biol. Chem. 193, 265.

Nakane, P.K. and Kawaoi, A. (1974) Peroxidase-labeled antibody, a new method of conjugation. J. Histochem. Cytochem. 22, 1084.

Norrby, E. (1985) Mumps virus. In: E.H. Lennette, A. Balows, W.J. Hausler and H.J. Shadomy (Eds.), Manual of Clinical Microbiology. 4th edit. American Society for Microbiology. Washington. D.C.

Nowinski, R.C., Tam, M.R., Goldstein, L.C., Stong, L., Kuo, C.C., Corey, L., Stamm, W.E., Hunter Handsfield, H., Knapp, J.S. and Holmes, K.K. (1983) Monoclonal antibodies for diagnosis of infectious diseases in humans. Science 219, 637.

Örvell, C. (1984) The reactions of monoclonal antibodies with structural proteins of mumps virus. J. Immunol. 132, 2622.

Van Tiel, F.H., Boere, W.A.M., Vinjé, J., Harmsen, M., Benaissa-Trouw, B.J., Kraaijeveld, C.A. and Snippe, H. (1984) Detection of Semliki Forest virus in cell culture by use of an enzyme immuno assay with peroxidase-labeled monoclonal antibodies specific for glycoproteins E1 and E2. J. Clin. Microbiol. 20, 387.

Van Tiel, F.H., Boere, W.A.M., Harmsen, M., Benaissa-Trouw, B.J., Kraaijeveld, C.A. and Snippe, H. (1985) Enzyme-immunoassay of interferon with peroxidase-labeled virus specific monoclonal antibodies. J. Gen. Virol. 66, 1353.

Van Tiel, F.H., Harmsen, M., Wagenaar, M., Boere, W.A.M., Kraaijeveld, C.A. and Snippe, H. (1986a) Rapid determination of neutralizing antibodies to Semliki Forest virus in serum by enzyme immunoassay in cell culture using virus specific monoclonal antibodies. J. Clin. Microbiol. 24, 665. 
Van Tiel, F.H., Harmsen, M., Kraaijeveld, C.A. and Snippe, H. (1986b) Inhibition of Semliki Forest virus multiplication by ribavirin: a potential method for the monitoring of antiviral agents in serum. J. Virol. Methods 14, 119.

Wagenvoort, J.H.T., Harmsen, M., Khader Boutahar-Trouw, B.J.. Kraaijeveld, C.A. and Winkler, K.C. (1980) Epidemiology of mumps in the Netherlands. I. Hygiene 85, 313.

Yamane, I., Matsuya, Y. and Jimbo, K. (1968) An autoclavable powdered culture medium for mammalian cells. Proc. Soc. Exp. Biol. Med. 127, 335. 